\title{
The Life and Opinions of Nelson Goodman - A Very Short Introduction ${ }^{1}$
}

\begin{abstract}
Nelson Goodman was an eminent philosopher and a passionate art collector. The first section of this introductory essay provides some biographical information with special emphasis on Goodman's education and academic career. The second part gives a survey of his major works and highlights their most distinctive contributions. The final section throws a glance at the still imperfect reception of his rich legacy.
\end{abstract}

\section{Life}

Nelson Goodman was one of the outstanding thinkers of the 20th century. In a memorial note in the Harvard University Gazette (1998), Hilary Putnam considers him to be "one of the two or three greatest analytic philosophers of the post-World War II period". 2

Goodman has left his mark in many fields of philosophical investigation. Whether Epistemology, Philosophy of Science, Logic, Metaphysics, the General Theory of Symbols, Philosophy of Language or Philosophy of Art, all have been challenged and enriched by the problems he has shown up, the projects he developed from them and the solutions he has suggested. Non-philosophical disciplines, too, - from measurement theory (cf. e.g. Grunstra 1972) to linguistics (cf. e.g. Heydrich 1982, 1993), literary criticism (cf. e.g. Scholz 1984; Ihwe 1985; Thürnau 1994) and art education - build on his findings. In further fields we may yet expect his ideas to be taken up.

${ }^{1}$ This is a revised and extended version of (Scholz 2005). I am grateful to Morton G. White, Catherine Z. Elgin, Henry S. Leonard, Jr., Karlheinz Lüdeking, Daniel Cohnitz and Marcus Rossberg for personal communication and advice. For his translation of my German text I want to thank Rudolf Owen Müllan (Hughes). A much more comprehensive and thorough introduction in Goodman's philosophy is now available in (Cohnitz; Rossberg 2006).

${ }^{2}$ Quoted in (Cohnitz; Rossberg 2006, 11). 
Goodman's contributions are characterized by their fundamental and farreaching importance, great originality as well as a rare combination of rigor and elegance. Reconceptions in Philosophy and Other Arts and Sciences, the title of a book he wrote together with Catherine Z. Elgin, could stand as the heading for his entire œuvre. Goodman has analyzed, criticized and rejected a host of traditional answers to fundamental philosophical questions in order to consequently reframe the issues and suggest innovative and often also provocative new solutions.

On August 7th 1906 Nelson Goodman was born the son of Sarah Elizabeth (Woodbury) Goodman (1874-1964) and Henry L. Goodman (1874-1941) in Somerville, Massachusetts. Entering Harvard in the 1920s, he was to witness the beginning of what has been termed "a second golden age in philosophy" (Lowe 1990, 149) ${ }^{3}$. If a first golden age that had been shaped by William James (1842-1910), Josiah Royce (1855-1916), George Herbert Palmer (1842-1933) and Hugo Münsterberg (1863-1916) came to an end with the death of the figureheads James and Royce, the inception of the second golden age was marked, in 1924, by the coming of Alfred North Whitehead $^{4}$ (1861-1947) and tenure being granted to Clarence Irving Lewis, who had been a member of the Philosophy Department since $1920 .^{5}$ Furthermore William Ernest Hocking (1873-1966), ${ }^{6}$ Ralph Barton Perry (1876-1957), ${ }^{7}$ James Haughton Woods $(1864-1935)^{8}$ as well as brilliant

${ }^{3}$ On this period of American philosophy cf. (Kuklick 2001, Chapter 9: Pragmatism at Harvard, 1878-1913).

4 Alfred North Whitehead (1861-1947) taught from 1924 through 1937 (official retirement) - and finally until 1941 (farewell lecture) - at Harvard University.

${ }^{5}$ Clarence Irving Lewis (1883-1964) taught from 1920 until 1953 at HarvardUniversity, since 1924 as a Full Professor. His main fields of scholarly interest were logic, epistemology and ethics. His textbooks on logic, A Survey of Symbolic Logic (Berkeley 1918) and (together with C. H. Langford) Symbolic Logic (New York 1932), which went through several editions, were widely disseminated. On his works cf. the contributions in (Schilpp 1968). Cf. also (Kuklick 2001, 214-220).

${ }^{6}$ William Ernest Hocking (1873-1966) taught at Harvard-University from 1914 until 1943; he was influenced by Kuno Fischer, Wilhelm Dilthey and Wilhelm Windelband. He has given a vivid image of Harvard during these years in Hocking 1961 (cf. also Kuklick 1977; Lowe 1990, chapter VII).

${ }^{7}$ Ralph Barton Perry (1876-1957), as a student and successor of William James, taught at Harvard-University from 1913 until 1946. Among his works is book with the 
young scholars like Henry Maurice Sheffer (1883-1964), ${ }^{9}$ Ralph Monroe Eaton (1892-1932) ${ }^{10}$ und Harry Austryn Wolfson (1887-1974) ${ }^{11}$ were members of the department. In Gordon Allport (1897-1967), Edwin G. Boring (1886-1968) and L.T. Troland (1889-1932) three outstanding psychologists were added to the mix.

Despite Goodman's interests in literature ${ }^{12}$ and mathematics as a student, he already decided on philosophy in his first semester - in a seminar "on the early history of philosophy, on Thales, Empedocles and the other Presocratics. I immediately knew that philosophy was the right thing for me." ${ }^{\prime 3}$ C.I. Lewis became his most influential philosophical teacher and

programmatic title The New Realism: Cooperative Studies in Philosophy (1912). Cf. (Kuklick 2001, 202ff).

${ }^{8}$ James Haughton Woods (1864-1935), after studying in Harvard, Cambridge (England), Berlin and Straßburg, taught at Harvard-University since 1913. In addition to Plato, Asian philosophy and religion were among his fields of research. In grateful memory Goodman mentions him in his dissertation - "To the late James H. Woods I owe a great debt for the kindness and encouragement which first led me to undertake this work." (Goodman 1940, i) - and in the preface to the first edition of The Structure of Appearance: "[...] I owe lasting gratitude to the late Professor James Haughton Woods for the indispensable initial spark of encouragement." (SA (1951), VII; SA (1977), XVII.)

${ }^{9}$ Henry M. Sheffer (1883-1964), a distinguished logician, taught at HarvardUniversity from 1908 until 1952. Among his works are: "A set of five independent postulates for Boolean algebras, with application to logical constants" (Sheffer 1913).

${ }^{10}$ Ralph Monroe Eaton (1892-1932) was Harvard instructor from 1919 until 1926, Assistant Professor from 1926 until 1932, Department Chairman from 1926 until 1930. His book Symbolism and Truth: An Introduction to the Theory of Knowledge published in 1925 was compared to Wittgenstein's Tractatus. On his life, which came to an early and tragic end, cf. the obituary in The Philosophical Review 6 (1933), 212213, also (Kuklick 1977, 458f).

${ }^{11}$ Harry Austryn Wolfson (1887-1974) taught at Harvard University until 1958 (cf. Kuklick 1977, 457). He made a name for himself as an expert on Neoplatonist and Medieval Philosophy and as a Spinoza scholar. A professorship at the Brandeis University was named after him, which Goodman held from 1964 until 1967. (See below.)

${ }^{12}$ Goodman initially wanted to become a writer.

${ }^{13}$ Nelson Goodman in conversation with Karlheinz Lüdeking (Goodman 2005, 264). It seems reasonable to conjecture that he was talking of a seminar by the abovementioned James Haughton Woods. 
gave him several ideas for his early works. In a recollection of his fellow student and year-long comrade-in-arms Henry S. Leonard (1905-1967) ${ }^{14}$ Goodman has given a witty account of their first years as students:

Our introduction to philosophy included the historic running debate over idealism versus realism between W.E. Hocking and Ralph Barton Perry, and over monism and pluralism in logic between C.I. Lewis and Harry Sheffer. We were absorbed by Lewis' courses in the theory of knowledge, based on the just published Mind and the World Order, ${ }^{15}$ and we were first exasperated and then enthralled by the nearly incoherent but inspired and profound lectures of James Haughton Woods on Plato. We sharpened our philosophical teeth in almost daily discussions of such matters as Berkeley's idealism, Plato's theory of ideas, Whitehead's extensive abstraction, ${ }^{16}$ and problems in logic (Goodman 1969, ix).

Goodman received his B.Sc. in 1928 (Phi Beta Kappa, magna cum laude) and his Ph.D. - also from Harvard - in 1941 with A Study of Qualities (1940), which he later elaborated in his first major work, The Structure of Appearance (1951). The relatively long period of time to his dissertation is explained by a number of circumstances.

${ }^{14}$ Henry S. Leonard (1905-1967) studied under Whitehead and Lewis. Together with Leonard Goodman developed a new version of mereological nominalism, the "calculus of individuals". Leonard "also first proposed trying direct application of symbolic logic to some philosophical problems we had been working on. This resulted in our joint article "The Calculus of Individuals", and in some other material incorporated in his doctoral thesis, 'Singular Terms', and in my own later work." (Goodman 1969, x). Cf. Leonard's Dissertation (Leonard 1930), (Leonard; Goodman 1949) as well as (Goodman, 1940) and $S A$.

15 Mind and the World Order published in 1929 is Lewis's first major work in epistemology; In it Lewis develops his influential strict version of epistemological fundamentalism. (The distinction between qualia and object properties was adopted from this work by Goodman. Cf. (Goodman 1940, 5n) and (SA (3. Aufl. 1977), 95n) Cf. also the further developments in: (Lewis 1946) and (Lewis 1952). In many works Goodman dealt with the writings of his teacher, cf. especially "Sense and Certainty" (Goodman 1952) and "Snowflakes and Wastebaskets" (in PP, 416-419).

16 Whitehead developed his method of extensive abstraction, which Goodman mentions in his report, in his book An Enquiry concerning the Principles of Natural Knowledge (Whitehead 1919). Of Whitehead's works the contributions to mereological geometry must have been most interesting to Goodman. With reference to Whitehead's definition of geometrical points Goodman liked to explicate methodological questions of constructional definition (cf., for instance, $S A, 5-7$ ). 
First and foremost, in this context, one has to mention Goodman's great passion for the arts. An intense commitment to all practical and theoretical questions of the artworld formed a major part of his life since the 1920s. In the seminars and colloquia given by the famous Museum director, collector and connoisseur Paul Joseph Sachs (1878-1965) on "Museum Work and Museum Problems", Goodman had not merely learned the basics of art history and art appreciation. He had become aware of how profound the difference is between cursorily glancing at pieces of art in museums or catalogues and an intense immersion in the original. Sachs invited his best students into his home and showed them originals in his possession or from the inventory of the William Hayes Fogg Art Museum, which belongs to Harvard. With his lively and practically oriented teaching style he managed to fill generations of students with enthusiasm for curatorial work and collecting art. ${ }^{17}$ Another student of Sachs', John Walker put it thus: "He was someone who really made you want to be a collector. None of the rest could. They could teach you the history of art, but Paul was the one that made us all want to be collectors" (Ciniglio 1976; also quoted in Alexander 1997, 213). Goodman's passion for collecting art, too, was awakened. With a wink he commented that, ever since, he had been constantly bankrupt. $^{18}$

From 1929 to his army draft in 1941, Goodman was the director of the Walker-Goodman Art Gallery at Boston's Copley Square. There he was also to meet his later wife, Katherine Sturgis (1904-1996), a Cambridge artist, who visited the gallery in order to exhibit her watercolour paintings and Indian ink drawings. ${ }^{19}$ Henceforth, Goodman led a double life between philosophy and the arts. Museums, art fairs and auction houses were home to him just as much as conventions on logic, epistemology or aesthetics. His friend, Curtis L. Carter of the Haggerty Museum of Art at Marquette University retrospectively comments:

${ }^{17}$ On the pre-eminent importance of Sachs for the American museum world cf.. (Alexander 1997, Chapter 13: Paul Joseph Sachs Teaches a Pioneering Course in Museum Studies).

18 Nelson Goodman in conversation with Karlheinz Lüdeking (Goodman 2005, 264).

${ }^{19}$ Goodman's readers know one of her works from the essay "The Status of Style" (reprinted in $W W$; the picture of the drawing is found on p. 30). 
Goodman's professional role as a gallery director and his private art collecting were sources of great satisfaction. His life-long pursuit of collecting art began in his student days. He was well known in the artworld for his discriminating aesthetic perception and equally for his astuteness in negotiating the price of an object. A visit to his home in Weston, Massachusetts would reveal a collector with enthusiasm an in-depth knowledge over a wide range of art (Carter 2000, 252).

The second reason for his delayed academic career is to be sought in his contemporary circumstances, which are easily forgotten today. "Because of his Jewish heritage, Goodman was ineligible for graduate fellowships" (Elgin 2000, 2). ${ }^{20}$ W.V. Quine (1908-2000), who was aware of Goodman's circumstances of living, recommended him to Rudolf Carnap (1891-1970) for a job as an assistant. It is worthwile quoting from this letter of recommendation:

My next recommendation would be H. Nelson Goodman, 607 Boylson St., Boston. Candidate for Ph.D. Age about 30. Very competent and industrious. An authority on the Logischer Aufbau, and conversant with your later work. Well grounded in philosophy and logic. As you know, he is in business - which accounts for the lateness of his Ph.D. I am not sure that he would not be interested in the assistantship. Teaching experience and publications none (Creath (ed.) 1990, 233). ${ }^{21}$

As the institutional framework of Carnap's professorship eventually did not turn out to be what had initially been promised to him, nothing came of this assistantship, from which both philosophers would undoubtedly have profited.

A third reason, which is not to be forgotten, is the high standard of the topics dealt with by Goodman. Among experts, A Study of Qualities has the reputation of being the most demanding and best doctoral dissertation ever handed in at Harvard. To his later co-author, Catherine Z. Elgin, he described his policy concerning scholarly projects as follows: "When you finish one project, ask yourself what is the most difficult outstanding problem in philosophy. Then work on that" (Elgin 2000, 2).

${ }^{20}$ Cf. (Schwartz 1999, 8): "This detour in career reflected both his passion for art and the difficulties with which someone of Jewish parentage then faced in academia".

21 The correspondence between Carnap and Quine contains further material on Goodman's temporary co-operation with Quine, the first meetings with Carnap and other, related events. Cf. (Creath (ed) 1990, 191, 194, 201-204, 212, 235, 295, 397, 420, 422f., 434, 454, 460, 465). 
After World War II, throughout which Goodman had been entrusted with carrying out psychological experiments for the U.S. Army, he worked as an Instructor in Philosophy at Tufts University for a brief interval. From there he went to the University of Pennsylvania, where he taught from 1946 to 1964, first as an associate professor and after 1951 as a full professor. From 1964 to 1967 he was Harry Austryn Wolfson Professor for Philosophy at Brandeis University. In 1968 he finally returned to Harvard University, where he taught till 1977.

It is there also that he founded "Project Zero", 22 in the context of which psychologists and philosophers study the cognitive skills that are developed while creating, understanding and judging works of art. This project, one of the foci of which is investigating how theoretical and practical competence in the arts can be refined, has had a significant impact on Art Education in the United States. At Harvard, Goodman was also involved in the founding of the Dance Center and of the Institute for Arts Administration, he was head of the Arts Orientation Series (1969-1977) and for many years was an advisor of Arts for Summer School (19711977).

A less well known fact is that Goodman designed three multimedia performance events, in the realisation of which he actively participated:

1) Hockey Seen: A Nightmare in Three Periods and Sudden Death, together with the choreographer Martha Armstrong Gray, the composer John Adams and Goodman's wife, the artist Katherine Sturgis, performed 1972 at Harvard, 1973 in Philadelphia and 1980 at Knokke-le-Zoute (Belgium), made into a Belgian Television production in 1980 and into a film at Harvard in $1984 ;^{23}$

22 "I founded Project Zero in 1967 at the Harvard Graduate School of Education and directed it for four years. Since then it has been directed by David Perkins and Howard Gardner. The research is conducted by a varying group of psychologists, philosophers, and others, paid and unpaid, and has been reported in a number of books and papers." $(M M, 147)$ The name "Project Zero" alludes to the awareness of having to start at zero. First results have been published in: (Leondar; Perkins 1977) as well as in $W W$ and $M M$, especially Part V.

23 "One production of Hockey Seen was sponsored by a professional hockey team and attended by many of its members. They gave it a good review." (Elgin 2000, 3.) From September 28, 2006 through January 14, 2007 Hockey Seen was presented again 
2) Rabbit Run, after a novel by John Updike, together with the choreographer Martha Armstrong Gray and the composer Joel Kabakov, as well as

3) Variations, An Illustrated Lecture Concert. At the heart of the latter stood twenty-two variations by Pablo Picasso on Diego Velazquez' painting Las Meninas, which Goodman had selected and arranged in a certain order. To this picture and its variations, which were shown as slides, the composer David Alpher composed a theme, also with twentytwo variations, which provided the score to the Lecture Concert. The programme was staged in different shapes at the University of Helsinki, at the Wayne State University, at the Rockport (Massachusetts) Chamber Music Festival, at Harvard University and at Trinity University in Texas. ${ }^{24}$

Over the years Goodman received several honours, among them four honorary doctorates, one of them from the Technische Universität Berlin. He delivered the Sherman Lectures at the University of London, the John Locke Lectures in Oxford, the Alfred North Whitehead Lecture at Harvard, the Immanuel Kant Lectures at Stanford and the Howison Lecture at Berkeley. In 1991, Goodman was honoured with an Author's Colloquium at the Centre for Interdisciplinary Research (Bielefeld, Germany). ${ }^{25}$

In his academic environment Goodmann had a reputation for being very strict, demanding and unapproachable. His impatience with slow-witted colleagues and students was feared. A description recurrent in all obituaries runs as follows: "he did not suffer fools gladly" (cf., for instance, Elgin; Scheffler; Schwartz 1999, 207; Elgin 2000, 1; Mitchell 1999). He placed high demands on himself and felt justified in also expecting a lot from others.

in the context of a multi-media exhibition at the Haggerty Museum of Art (Marquette University, Milwaukee).

${ }^{24}$ Cf. ( $R$, Chapter IV), especially the references on p. 81 as well as (Carter 2000, 252) and (Elgin 2000, 3). - According to David Alpher's homepage, Variations has by now seen over 25 performances worldwide.

25 The records of this colloquium organized by Peter Bieri and myself were published in a special edition of the journal Synthese, Vol. 95, No. 1, April 1993, cf. my introduction (Scholz 1993a). 
The best scholars took their hats off to Goodman's unrelenting sharp wit. In such a vein Sir Alfred Jules Ayer (1910-1989) in his autobiographical writings freely reports on an encounter unforgettable to him:

My inaugural lecture "Thinking and Meaning" was published as a pamphlet in 1947. I still believe that it posed some of the right questions but doubt if it gave many of the right answers to them. When I repeated it before a small audience of philosophers in New York in 1948 Nelson Goodman raised objections to it which I could not meet (Ayer, in: Hahn 1992, 23). ${ }^{26}$

From the published replies to objections one gets an idea of the mental presence characteristic of Goodman in conversation.

After having formally been made Professor Emeritus in 1977 Goodman can hardly be said to have retired. He published three further books full of new and provocative ideas: 1978 Ways of Worldmaking $(W W), 1984$ Of Mind and Other Matters (MM) and together with Catherine Z. Elgin 1988 Reconceptions in Philosophy and Other Arts and Sciences $(R)$. He wrote replies and retractations for the volume Starmaking (McCormick 1996), which contains old and new contributions to the issue of pluralism about worlds. With the imaginativeness and optimism characteristic of him he further investigated the perspectives laid out in his early works.

That his works incurred increasing interest in Europe, too, filled Goodman with obvious joy. On his countless travels he would not be robbed of visiting the great art fairs and exhibitions of the whole world.

A fact hardly known is that Goodman and his wife were passionate animal lovers and committed animal conservationists. They always had dogs around them; their names are listed in the dedication of Of Mind and Other Matters: "To Snubby, Tweedledee, Randy, Angie, Debby, Susan, Trushka - for help and hindrance". As members of the World Society for the Protection of Animals and similar organisations, the Goodmans generously supported campaigns to save animals which were endangered by wars such as, for instance, the first Gulf War or the War in Bosnia, or by natural disasters.

${ }^{26} \mathrm{Cf}$. also the detailed report in the second part of Ayer's autobiography (Ayer 1985, 47). Ayer has respectfully acknowledged Goodman's œuvre in (Ayer 1982, 253262). 
Until shortly before his death, Goodman was working on a lecture which he wanted to deliver at a conference in Heidelberg. ${ }^{27}$ The fact that until the very end he was absolutely determined to travel to Germany in order to deliver his lecture and reconvene with his friends is very characteristic of his constantly future-oriented thinking and striving. However, it never came to this journey. On November 25th 1998 Nelson Goodman died at the age of 92 in Needham, Massachusetts.

His steady gaze ahead and the corrolary reluctance to comfortably look back on his achievements are to be seen as the reason why we know so little about his life first-hand, whether spoken or written. ${ }^{28}$ Thus, he rejected the not insignificant honour of a volume in the series Library of Living Philosophers (cf. Elgin 2000, 2). An Intellectual Autobiography as it characteristically opens the volumes of this series held no attraction for him whatsoever. He preferred to look ahead and continue his work.

\section{Opinions}

Even though Goodman placed highest demands on his publications ${ }^{29}$, over the course of his long life, a considerable auvre developed, which comprises eight books ${ }^{30}$ and several essays and other smaller works.

27 A volume dedicated to the commemoration of Nelson Goodman with the title Wirklichkeit und Welterzeugung. In memoriam Nelson Goodman (Fischer; Schmidt 2000) came out of this conference. It is, however, doubtful whether everything that is debated in this volume under the ambiguous heading "constructivism" really is in the spirit of Goodman's constructional philosophy.

${ }^{28}$ Goodman only rarely gave interviews; the most insightful one - the conversation with Karlheinz Lüdeking - is printed as a translation into German in (Steinbrenner; Scholz; Ernst 2005, 261-269). (The only further authorized interview, which was recorded for Belgian television in August 1980, has been published as an appendix to $M M$, pp. 189-200.)

29 The high standard is epitomized by the fact that his first works were accepted and published by the Journal of Symbolic Logic.

${ }^{30}$ Counting A Study of Qualities (1940; printed 1990), which was elaborated in The Structure of Appearance (1951; $3^{\text {rd }}$ edition 1977). This is justified because it contains important passages that were not taken over in $S A$. The volume Starmaking (McCormick 1996), which also contains, aside from Goodman's replies, contributions by other philosophers. 
That Goodman was quite the opposite of a hasty and profuse writer is most impressively witnessed by the genesis of his dissertation and its history of publication.

First thoughts toward the thesis began to occur during my undergraduate years, 1924-1928, at Harvard. $\left[{ }^{31}\right]$ A 'finished version' was ready by 1933, but the project had by then expanded enough to take another seven years. Still, hundreds of changes were made from thesis to book (Goodman 1940, preface).

The constantly reworked book was finally published in 1951 under the title The Structure of Appearance. ${ }^{32}$

Goodman's first major work is doubtless his most demanding and difficult book; unfortunately it has also remained his least well-known work. This is regrettable for several reasons. First, of course, because it contains so many ideas and develops projects, which were taken up and developed further only by a few specialists. Second, this book already contains the seeds of later works, which are hardly comprehensible without this background. This is true particularly of Ways of Worldmaking, the "radical relativism under rigourous restraints" $(W W, \mathrm{x})$ which is often received in a watered-down form, because the results of the earlier work are not taken into account.

In continuation and critical analysis of Our Knowledge of the External World (1914) and other works by Bertrand Russell (1872-1970), Mind and the World Order (1929) by C.I. Lewis (1883-1964) and most importantly Der logische Aufbau der Welt (1928) by Rudolf Carnap (1891-1970), Goodman develops his own constructional philosophy and provides a host of constructional systems for characterising the formal structure of

${ }^{31}$ Goodman stressed in conversation that he had already been working on the questions he deals with in his dissertation before the publication of Der logische Aufbau der Welt (1928). This work having been pointed out to him (probably by C.I. Lewis, maybe also by Henry S. Leonard, who was in Munich in 1929), it did, of course, become the work, against which he most set himself of throughout his further work. (As Carnap's work would only be translated into English in 1967 (cf. Carnap 1967), Goodman had to translate it himself). In any case, the widespread opinion that Goodman's early works are simply a reaction to Carnap's Aufbau has to be revised.

${ }^{32}$ A second, revised edition was published in 1966, a third one, once again revised, in 1977. The typed version of $A$ Study of Qualities that Goodman had handed in was only to be published in 1990 . 
experience, in particular a detailed phenomenalist system, as it were: "a structure of appearances". Among the many further riches contained within this work, one may mention: "the calculus of individuals", a version of formal mereology which Goodman had developed together with Henry S. Leonard as a graduate student, a theory of simplicity (of predicates), systematic investigations of ordering, measurement, time and a theory of indexical expressions, especially temporal deixis. ${ }^{33}$

At that stage already, an anti-absolutist pluralism had become the hallmark of Goodman's philosophy. In the preface to his dissertation (1940!) he writes: "Perhaps the conviction I should acknowledge most willingly is that absolutism must be rejected" (Goodman 1940, v). He continues his confession in a way particularly characteristic of his constructional philosophy:

But nothing is much emptier than a relativism that, without seeking to find any solution to a given problem, merely expresses a willingness to admit alternative solutions. Freedom has little value if we use it solely to declare that we have it. The recognition that theoretically there are many equally satisfactory systems is but the first step in the laborious task of realizing at least one of them (Goodman 1940, v).

Goodman has taken up this task in the main parts of A Study of Qualities and The Structure of Appearance; the result is a detailed phenomenalist system with qualia as atoms. The cognitive aim of such system building is explained by Goodman as follows:

[...] the purpose of constructing a system is to interrelate its predicates. The same purpose is served by reducing to a minimum the basis required. Every definition at once both increases the coherence of the system and diminishes the number of predicates that need be taken as primitive. Thus the motive for seeking economy is not mere concern for superficial neatness. To economize and to systematize are the same $(S A, 47 \mathrm{f})$.

An appropriate appreciation of this first major work, pioneering methodically as well as with regard to content, is yet to be awaited. ${ }^{34}$

\footnotetext{
${ }^{33}$ The best introduction to Goodman's first major work, its position in the œuvre as a whole and in contemporary philosophy still is Geoffrey Hellman's "Introduction", which is prefaced to the third edition (Dordrecht, Boston 1977), pp. XIX-XLVII.

${ }^{34} \mathrm{Cf}$. the abovementioned "Introduction" to the third edition by Geoffrey Hellman.
} 
In the summer of 1947 a very lively correspondence ${ }^{35}$ ensued between Goodman, W.V. Quine and Morton G. White, from which influential works emerged that attacked the analytic-synthetic distinction and connected terms like intensional synonymy, apriority, metaphysical necessity etc. At the end of this correspondence, Morton White was chosen to give a critical overview of the issues, a task which he carried out in an exemplary way in "The Analytic and the Synthetic: An Untenable Dualism" (White 1950). Quine's essay "Two Dogmas of Empiricism", in which he drew far-reaching philosophical and metaphilosophical conclusions from the failure of attempts to give satisfactory definitions of the incriminated terms, became much more famous.

Goodman's reaction was different in a telling way. While he gave an extensional explication of "likeness of meaning" in "On Likeness of Meaning", which is capable of replacing an absolute concept of synonymy by a workable one ${ }^{36}$, he did not participate in the hustle and bustle caused by the discussion of the analytic-synthetic distinction and, in particular, the essay "Two Dogmas". Instead of painting a gloomy picture of the possible consequences of the absence of an absolute distinction, Goodman preferred to continue his work - without relying on terms as questionable as analyticity, necessity, essential property or natural kind. Goodman was always more interested in philosophy than in meta-philosophy.

In accordance with his above-quoted policy to always seek out the greatest challenge, in the works culminating in the book Fact, Fiction, Forecast (FFF) (1954), he turned his attention to the most intricate complex of problems in epistemology and the philosophy of science. The issues can be outlined by the following titles: "dispositions", "potentiality", "counterfactual conditionals", "inductive confirmation" and "natural laws". Fact, Fiction, Forecast, in a particularly impressive way, exemplifies Goodman's method of "reconception" or, as one might say, fruitful transference of problems. A number of significant achievements may be

35 On this episode of importance to the philosophy of the following decades cf. (Quine 1985, 226; 1960, 67, n. 7- 68; Wang 1986, 130-133; White 1999 as well as Creath 1990, 35). This volume also contains Carnap's first reaction to "Two Dogmas", cf. (ibid., 427-432). The correspondence between White, Quine und Goodman is now published in the appendix to (White 1999, 337-357).

${ }^{36} \mathrm{Cf}$. (Heydrich 1993) with an important amendment and further references. 
distinguished within this small book: As a start, Goodman has put forward an analysis of the specific character of the above-mentioned philosophical problems. Goodman not only shows that all of these problems are so far unsolved, but also that they are thoroughly intertwined. Their solution presupposes the resolution of a much more general problem so far hardly recognised, let alone overcome: How do lawlike statements differ from non-lawlike, accidental generalisations? In so doing, in particular, the traditional problem of induction is reconceived. For one part it can be solved, for another part it has to be dissolved to uncover a real and general problem: the problem of law-likeness, that is, more generally the problem of projection (of statements and the predicates occurring in them) from one set of cases to another one. Finally, Goodman has undertaken the first steps towards developing a general solution to this ubiquitous problem (Chapter 4).

The so-called problem of justifying induction is dissolved if it is understood as the search after guarantees for hypotheses. Understood in this way the problem turns out to be simply a curious attempt to justify knowledge we do not possess. It is, however, possible to solve another problem: One can give a general answer to the question of how rules of inductive inference are justified. Rules of inductive reasoning are codifications of an antecedent practice; they are justified if they adequately represent this practice:

A rule is amended if it yields an inference we are unwilling to accept; an inference is rejected if it violates a rule we are unwilling to amend. The process of justification is the delicate one of making mutual adjustments between rules and accepted inferences; and in the agreement achieved lies the only justification needed for either $(F F F, 64)$.

For this method of mutual adjustment the term "reflective equilibrium" has become commonplace since John Rawls' A Theory of Justice (1971), in which it has been applied to moral principles (Rawls 1971, 20; cf. also Daniels 1996; Hahn 2000).

The new riddle of induction shows that syntactic (formal) and semantic conditions are not sufficient to draw the dividing line between valid and invalid inductive inferences. In retrospect, Goodman notes: “[...] we may by now confidently conclude that no general distinction between projectible and non-projectible predicates can be drawn on syntactic or 
even on semantic grounds." $(P P, 357)$. Inductive Logic, if at all one can speak of such a thing, cannot be formal in the same way as deductive logic is.

In the conclusion of his book Goodman has suggested a solution, which makes use of the pragmatic term "entrenchment", i.e. the historical anchoring of a predicate in linguistic practice. The relative projectibility of generalisations is primarily determined by the relative anchoring of the predicates occurring in it, i.e. by the extent to which these predicates have been used in previously projected generalisations.

In this way the concepts of confirmation and lawlikeness are relativised to linguistic practices. In the pragmatic-historical theory past projections, i.e. earlier projections from known to unknown cases, have to be taken into account in judging the lawlike character. It is insightful to see how Goodman locates his suggestion between Hume and Kant:

Like Hume, we are appealing here to past recurrences, but to recurrences in the explicit use of terms as well as to recurrent features of what is observed. Somewhat like Kant, we are saying that inductive validity depends not only upon what is presented but also how it is organized; but the organization we point to is effected by the use of language and is not attributed to anything inevitable or immutable in the nature of human cognition. To speak very loosely, I might say that in answer to the question what distinguishes those recurrent features of experience that underlie valid projections from those that do not, I am suggesting that the former are those features for which we have adopted predicates that we have habitually projected $(F F F, 97)$.

Had Goodman written only this book, he would already have been granted a place of honour in the history of philosophy. ${ }^{37}$ The renowned philosopher of science Ian Hacking in retrospect commented on the problems and riddles brought up by Goodman: "They combine precision of statement, generality of application, and difficulty of solution to a degree greater than any other philosophic problem broached in this century" (Hacking 1965, 41).

37 The discussion is documented in: (Stalker 1994). This volume contains an extensive commented bibliography. - A selection of the most important contributions with an instructive introduction is reprinted in: (Elgin 1997). Applications and Conclusions in the fields of social sciences and medicine are examined in: (Douglas; Hull 1992). 
In the 60ies, for the first time, Goodman brought together his two great passions - theoretical philosophy and the arts - in his research and his publications, too. From a thorough epistemological and semiotic study of the arts in 1968 the third book emerged, Languages of Art, which was also to achieve epoch-making status.

In this approach to and outline of a general theory of symbols the structures of various symbol systems as they function in everyday life, in the arts and in the sciences are illuminated by astute analyses and constructive comparisons. The manifold forms of symbolisation in the arts are, and this is one of Goodman's major points, of an importance in our cognitive endeavours equal to that of theories, formulae and diagrams in the sciences. Works of art are, just like scientific systematizations, complex symbols, which we create, apply and interpret in our striving for knowledge and understanding.

In the book semiotic, aesthetic and epistemological investigations run together. As subheading and introduction emphasise the primary aim is the development of a general theory of symbols which is intended to illuminate the various symbol systems in everyday life, science and technology as well as in the arts. The term "symbol" is here understood in a very broad manner, covering "letters, words, texts, pictures, diagrams, maps, models, and more" ( $L A, \mathrm{xi})$. Aesthetic questions serve as starting points and are given inventive solutions.

The first two chapters investigate two traditional aesthetic issues: the nature of pictorial representation (I) and the nature of aesthetic expression (II). Both relations are characterised semiotically as forms of reference. In the course of a sweeping critique of resemblance theories of pictures, representation is provisionally characterised as a subcase of denotation. In analysing the concept of expression, attention is drawn to the neglected semiotic relation of exemplification, in which an object, as a sample, refers to predicates it instantiates. That a work expresses a feeling or the likes comes down to its metaphorically exemplifying suitable predicates.

In chapter III a new strand begins that is only in the end brought together with the others. Goodman brings up the question of how it is possible in a given art that there are forgeries and thus a distinction between original and fake. There are fundamental differences between so-called autographical arts (like painting), in the case of which authenticity can only be confirmed 
historically, and allographical arts (like music), in the case of which the constitutive features of a work can be fixed by a notation. In this way, clarifying the differing criteria of identity for works of art leads to the task of investigating the nature and function of notational systems.

Chapter IV, the systematic centre-piece of the book, in the theory of notation develops a conceptual instrument, which makes possible the description and classification of symbol systems in general. Musical and other notational systems represent an illuminating borderline case of symbol systems: They are characterized by five requirements which are only partially or not at all satisfied in other symbol systems. Notational systems are syntactically disjoint and differentiated systems, they are free of ambiguities and are also semantically disjoint and differentiated. To simplify a bit, in a notational system a maximally high degree of syntactic and semantic definiteness is realised. ${ }^{38}$ Chapter $\mathrm{V}$ demonstrates up the fertility of the theory by applying it to music, the visual arts, literature, dance and architecture.

In the final chapter a few loose threads are then tied together. It is now possible to draw a clearer distinction between pictorial and verbal symbol systems (VI.1-2). Finally (VI.3-7), a cognitivist conception of the aesthetic and the arts is sketched (cf. Steinbrenner 1996; Ernst 2000; Scholz 2001). The arts, which, like the sciences, are cognitive practices, actively contribute to structuring, understanding and constructing the worlds in which we live. The contrast between the sciences and the arts is based on differences as to the dominance of features of the symbols used. Tentatively four "symptoms of the aesthetic" are given, to which Goodman added a fifth in Ways of Worldmaking (1978) (WW, 68). Languages of Art today already counts as a classic work in aesthetics; increasingly it is also receiving attention in discussions on semiotics and epistemology.

The collection of essays Problems and Projects (1972) contains important retractions from and further developments of ideas in the first three books as well as replys to criticisms. In part I Goodman speaks out on his understanding of philosophy, its aims and methods (cf. Cohnitz; Rossberg 2006, Chapter 3).

${ }^{38}$ For more elaborate accounts cf. (Scholz 1991; 2004, Chapter 4) and (Cohnitz; Rossberg 2006, Chapters 6 and 7). 
In subsequent works Goodman follows up on the far-reaching epistemological and metaphysical consequences of this general theory of signs. The symbols of the manifold systems do not provide passive representations of a world to be discovered, but go into constituting that which is referred to. In other words: They are constitutive of worlds. We are thus confronted with a plurality of scientific and artistic world versions, none of which can exclusively lay claim to be the true one. This pluralism is, however, not to be confused with an irresponsible relativism á la "anything goes"; for the difference between right and wrong world versions is not at all abandoned. The investigation of the respective standards of correctness moves centre-stage in Goodman's work, and it is plainly seen that the fulfillment of these standards is anything other than trivial. As mentioned above, in Ways of Worldmaking (1978) Goodman speaks of a "radical relativism under rigorous restraints" ( $W W, \mathrm{x}$; my emphasis). He adds:

Nevertheless, I think of this book as belonging in that mainstream of modern philosophy that began when Kant exchanged the structure of the world for the structure of the mind, continued when C.I. Lewis exchanged the structure of the mind for the structure of concepts, and that now proceeds to exchange the structure of concepts for the structure of the several symbol systems of the sciences, philosophy, the arts, perception, and everyday discourse. The movement is from unique truth and a world fixed and found to a diversity of right and even conflicting versions or worlds in the making $(W W, \mathrm{x})$.

The responses by top-class colleagues of Goodman as to this pluralism concerning worlds have been compiled in the volume Starmaking (1996) edited by Peter J. McCormick; in it Goodman responded, for the last time, to what he called "worldly worries". 39

In 1984, a further collection of essays was published, Of Mind and Other Matters (MM). Like Problems and Projects (PP) it also contains replies to criticisms and further developments. Most noteworthy are the developments of the general theory of symbols in Part III, particularly in the important paper "Routes of Reference", as well as few smaller papers on philosophical psychology in Part I.

39 It may be noted that Goodman's essay "On Some Worldly Worries" reprinted in this volume by McCormick had initially been published in the special edition of Synthese (Bieri; Scholz 1993). 
Goodman's provocative contributions have suggested again and again that prevalent conceptions of philosophical ideals like certainty, knowledge and truth have to be reconceived and revised. How this could be done is the subject of Goodman's last greater work, Reconceptions in Philosophy and Other Arts and Sciences (1988) (R), which he co-authored with Catherine Z. Elgin.

If all fields of cognition, all kinds of symbols and reference are considered, new guideline concepts need to be accorded central status, for instance: current adoption, understanding and correctness. ${ }^{40}$ Against the backdrop of the general theory of symbols and an epistemological and metaphysical pluralism Goodman and Elgin, in this book, propagate a revision and reorientation of philosophy.

The introductory chapter recapitulates the symbol-theoretic research program and its epistemological and metaphysical consequences: The symbols of everyday life, of the sciences and the arts do not simply describe an independently given world, they go into the constitution of what is referred to.

Nonetheless, rigorous restraints (nominalism) and standards of correctness (consistency, deductive and inductive correctness, rightness of categorisation etc.) hold for the construction of adequate world versions. In this sense constructionalist pluralism in no way comes down to an "irresponsible relativism".

Having given a diagnosis of the plight of prevalent epistemologies, the conclusion makes suggestions for due reforms. To account for all fields of cognition, all kinds of symbols and reference guideline concepts like "truth", "certainty" and "knowledge" need to be expanded or even replaced; as successors a concept of rightness of symbolic functioning, a concept of tentative adoption and a concept of understanding in a broad sense are recommended.

In the detailed studies in the middle part the fertility of this reorientation is shown for a semiotics of pictorial representation and architecture, for literary theory and for the cognitive sciences. In the final chapter "A Reconception of Philosophy" Goodman and Elgin also give a brief

\footnotetext{
${ }^{40}$ Cf. my review in the Frankfurter Allgemeine Zeitung (November $14^{\text {th }}, 1989$ ) as well as the relevant article in (Volpi 1999, 582-583).
} 
characterisation of the overall project as it emerged since Languages of Art (1968) and Elgin's With Reference to Reference (1983): ${ }^{41}$

We work from a perspective that takes in the arts, the sciences, philosophy, perception, and our everyday worlds, and toward better understanding of each through significant comparison with the others. Speaking schematically, the first phase of this effort begins by observing that the use - that is, the fabrication, application, and interpretation - of symbols is centrally involved in all these fields. Accordingly, a general theory of symbols and their functions is outlined $(L A ; R R)$. The second phase confronts the consequences of recognizing that symbols are not merely devices for describing objects, events, a world waiting to be discovered, but enter into the very constitution of what is referred to $(W W)$. The present third phase starts from the realization that the prevailing conception of philosophy is hopelessly deficient when all fields of cognition, symbols of all kind, and all ways of referring are taken into account, and so goes on to search for more comprehensive and responsive concepts $(R, 164)$.

However different the objects and applications of Goodman's philosophy have been, continuous characteristics are a strict form of nominalism, persistent criticism of the idea of "the given" and concomitantly an emphasis on the active, constructive and creative elements of perception, cognition and understanding. His epistemology is anti-fundamentalist; instead, Goodman recommends a coherentist conception of epistemic justification. Metaphysical points of contention should make room for methodological questions. In an allusion to a hope, which he had raised in the preface to the first edition of The Structure of Appearance, Goodman comments in the preface to the third edition:

Unfortunately, the hoped-for day when philosophy will be 'discussed in terms of investigation rather than controversy, and philosophers, like scientists, be known by the topics they study rather than the views they hold' has not yet come (SA, XIII).

\section{Reception}

During his lifetime Nelson Goodman already counted as one of the most important philosophers of the 20th century. Anyhow, a comprehensive reception of his complex œuvre is still in its beginnings.

${ }^{41}$ With Reference to Reference $(R R)$ is Elgin's attempt to systematize the theory of symbols developed by Goodman. Cf. my review (Scholz 1988, 336-340). 
If one looks to the United States, to begin with, it is to be noted that, while Goodman is being quoted and discussed all over, he has not, in the narrow sense, become the figurehead of a particular philosophical school. There are, however, a number of excellent students of his.

Two of his most famous students, Noam Chomsky (born 1928) and David K. Lewis (1941-2002) have, at an early stage, developed in directions quite different from their teacher. Chomsky and his students, most prominently Jerry Fodor, have revived the Cartesian doctrine of innate ideas, which Goodman finds mistaken, even incomprehensible. ${ }^{42}$ And David Lewis tried to rehabilitate concepts, which had been discredited by Goodman and Quine.

Among those who sought to further develop and communicate his ideas to a wider audience one might note Israel Scheffler, Catherine Z. Elgin, Joseph Ullian, Richard Rudner, Robert Schwartz, Margaret Atherton, Geoffrey Hellman and Marsha Hanen. ${ }^{43}$

With other outstanding philosophers there was temporary cooperation. The intermittent collaboration with Henry S. Leonard and W.V. Quine has already been mentioned. More recently Hilary Putnam, Goodman's colleague at Harvard, has pointed out a convergence of their positions. ${ }^{44}$ But despite this illustrious series of followers and allies Goodman has not, unlike, e.g., W.V. Quine, Donald Davidson or Michael Dummett, become the figurehead of an influential school in the Anglo-Saxon world.

Several reasons for this may be assumed. The most important of these may be taken to lie in the versatility of Goodman's œuvre and an unfortunately fragmented reception. Only a few have studied all of his major works, even less are capable of seeing the connections in terms of content and method between his contributions.

${ }^{42}$ Goodman dedicated two witty essays to the revival of the doctrine of innate ideas by Chomsky, which are reprinted in Problems and Projects (PP, 69-75, 76-79). Goodman's student's Margaret Atherton and Robert Schwartz, too, have repeatedly and critically dealt with innateness hypotheses à la Chomsky and Fodor.

${ }^{43} \mathrm{Cf}$. also the works mentioned in the bibliography, which are, of course, only a selection.

${ }^{44}$ Cf. the preface to his book Truth, Reason and History (1981). Putnam wrote a bright and empathic preface to the fourth edition of FFF (1983). 
In Great Britain Alfred Jules Ayer, whom we have quoted above, was one of the few admirers of Goodman's work. It seems that through Michael Dummett's harsh criticism of The Structure of Appearance the reception of Goodman's philosophy in England was all in all ill-omened (Dummett 1955, 1956, 1957). Peter Hacker sums it up thus: "It is true that philosophers in Oxford placed no faith in the kind of system-building Goodman had embarked upon in The Structure of Appearance" (Hacker 1996, 230). Retrospectively, however, Dummett commented: "I regret that I did not make more explicit the admiration that I felt for The Structure of Appearance" (Dummett 1978, xli). ${ }^{45}$

In contrast to the British Isles, there is a growing reception of Goodman's work in many other European countries, especially in Scandinavia, Belgium and, perhaps somewhat surprisingly, in France (cf. e.g. Genette 1992, 1994; Morizot 1996; Pouivet 1996).

In the German-speaking world the reception began very early. As early as in the 40ies Heinrich Scholz (1884-1956), then Professor for Philosophy at Münster University, asked Goodman to send him his first works in logic. (Goodman kept the postcards and later showed them to me.) In the Deutsche Literaturzeitung he tried to introduce The Structure of Appearance and Fact, Fiction, Forecast to the German audience (cf. Scholz 1951, 1958). Since the 50ies Wolfgang Stegmüller (Munich) has regularly pointed out Goodman's seminal contributions (cf. Stegmüller 1957, 1958/59, 1969, 1983). The journal Erkenntnis edited, at the time, by Carl G. Hempel, Wolfgang Stegmüller and Wilhelm K. Essler dedicated two special issues to Goodman's works in 1978 (Erkenntnis 12/1, 1978). Besides Stegmüller Franz von Kutschera (Regensburg), ${ }^{46}$ Guido Küng (Fribourg, Switzerland), ${ }^{47}$ Gottfried Gabriel (Jena), ${ }^{48}$ Jens Kulenkampff (Erlangen) ${ }^{49}$ and Günter Abel (Berlin, Technical University) ${ }^{50}$ deserve to be mentioned. In 1990, Goodman received an honorary doctorate from the

45 A thorough investigation and rejection of Dummett's criticism is given by Farrell (1974, 223-249).

\footnotetext{
${ }^{46}$ Cf. (von Kutschera 1972, 1975, 2005).

${ }^{47}$ Cf. (Küng 1967, 1993; Hottinger 1988).

${ }^{48}$ Cf. (Gabriel 1986, 1991, 1997, 2000; Thürnau 1994).

${ }^{49}$ Cf. (Kulenkampff 1978, 1981, 1997, 2005a, 2005b).

${ }^{50}$ Cf. (Abel 1991, 1993, 1999).
} 
Technical University Berlin. In 1991, he was honoured by an Author's Colloquium at the Centre for Interdisciplinary Research in Bielefeld, Germany (cf. Bieri; Scholz 1993).

In more recent years, a younger generation of Goodman aficionados emerged. In 1996, some of us met near Munich to celebrate his 90th birthday (cf. Steinbrenner; Scholz; Ernst 2005). Finally, in 2006, a conference Nelson Goodman: From Logic to Art - Looking Back on the Occasion of his $100^{\text {th }}$ Birthday was organized by Gerhard Ernst, Jakob Steinbrenner and me in Munich. This conference is documented in this volume.

\section{References}

Abel, G. (1991): "Logic, Art, and Understanding in the Philosophy of Nelson Goodman", in: Inquiry 34 (1991), 311-321.

Abel, G. (1993): Interpretationswelten: Gegenwartsphilosophie jenseits von Essentialismus und Relativismus, Frankfurt am Main: Suhrkamp, 1993.

Abel, G. (1999): Sprache, Zeichen, Interpretation, Frankfurt am Main: Suhrkamp, 1999.

Alexander, E.P. (1997): The Museum in America: Innovators and Pioneers, Walnut Creek: AltaMira Press, 1997.

Atherton, M. (1970): Nativism, Doctoral Dissertation, Brandeis University, 1970.

Atherton, M. (1990): Berkeley's Revolution in Vision, Ithaca; N.Y.: Cornell University Press, 1990.

Ayer, A.J. (1982): Philosophy in the Twentieth Century, London: Weidenfeld, 1982.

Ayer, A.J. (1985): More of My Life, Oxford: Collins, 1985.

Bieri, P.; Scholz, O.R. (eds) (1993): Probing into 'Reconceptions', in: Synthese 95, No. 1 (1993).

Carnap, R. (1928): Der logische Aufbau der Welt, 2nd Edition, Hamburg: Meiner, 1961. 
Carnap, R. (1967): The Logical Structure of the World and Pseudoproblems in Philosophy, translated by Rolf A. George, Berkeley; Los Angeles: University of California Press, 1967.

Carter, C.L. (2000): “A Tribute to Nelson Goodman", in: Journal of Aesthetics and Art Criticism 58 (2000), 251-253.

Ciniglio, A.V. (1976): "Pioneers in American Museums: Paul J. Sachs", in: Museum News 55 (1976), 69-70.

Cohnitz, D.; Rossberg, M. (2006): Nelson Goodman, Chesham: Acumen, 2006.

Creath, R. (ed.) (1990): Dear Carnap, Dear Van. The Quine-Carnap Correspondence and Related Work, edited with an Introduction by Richard Creath, Berkeley; Los Angeles; London: University of California Press, 1990.

Daniels, N. (1996): Justice and Justification. Reflective Equilibrium in Theory and Practice, Cambridge: Cambridge University Press, 1996.

Douglas, M. and Hull, D. (eds) (1992): How Classification Works: Nelson Goodman among the Social Sciences, Edinburgh: Edinburgh University Press, 1992.

Dummett, M. (1955): "Critical Notice: The Structure of Appearance", in: Mind 64 (1955), 101-109.

Dummett, M. (1956): "Nominalism", in: The Philosophical Review 65 (1956), 491-505.

Dummett, M. (1957): “Constructionalism", in: The Philosophical Review 66 (1957), 47-65.

Dummett, M. (1978): Truth and Other Enigmas, London; Cambridge (Mass.): Harvard University Press, 1978.

Eberle, R. (1970): Nominalistic Systems, Dordrecht: D. Reidel, 1970.

Elgin, C.Z. (1983): With Reference to Reference, Indianapolis: Hacket, 1983.

Elgin, C.Z. (1992): "Nelson Goodman", in: Jonathan Dancy und Ernest Sosa (eds): A Companion to Epistemology, Oxford: Blackwell, 1992, 162-164.

Elgin, C.Z. (1996): Considered Judgment, Princeton: Princeton University Press, 1996.

Elgin, C.Z. (1997): Between the Absolute and the Arbitrary, Ithaca, N.Y.: Cornell University Press, 1997. 
Elgin, C.Z. (1997b): "Nelson Goodman's New Riddle of Induction", in: Elgin, C.Z. (ed.): The Philosophy of Nelon Goodman: Selected Essays, New York: Garland, 1997.

Elgin, C.Z. (1998): “Goodman, Nelson", in: E. Craig (ed.), Routledge Encyclopedia of Philosophy, Vol. 4, London; New York: Routledge, 1998, 135-140.

Elgin, C.Z. (2000): "Worldmaker: Nelson Goodman (1906-1998)", in: Journal for General Philosophy of Science 31 (2000), 1-18.

Elgin, C.Z. (2001): "The Legacy of Nelson Goodman", in: Philosophy and Phenomenological Research 62 (2001), 679-690.

Elgin, C.Z. (2004): "Denying a Dualism: Goodman's Repudiation of the Analytic/Synthetic Distinction", in: Midwest Studies in Philosophy 28 (2004), 226-238.

Elgin, C.Z. (ed.) (1997): The Philosophy of Nelson Goodman. Selected Essays, Vol. 1-4, New York: Garland, 1997.

Elgin, C.Z.; Scheffler, I.; Schwartz, R. (1999): "Nelson Goodman 19061998", in: Proceedings and Addresses of the American Philosophical Association 72:5 (1999), 206-208.

Ernst, G. (2000): “Ästhetik als Teil der Erkenntnistheorie bei Nelson Goodman", in: Philosophisches Jahrbuch 107 (2000), 315-340.

Farrell, R. (1974): "Michael Dummett on the Structure of Appearance", in: Synthese 28 (1974), 223-249.

Fischer, H.R.; Schmidt, S.J. (eds) (2000): Wirklichkeit und Welterzeugung. In memoriam Nelson Goodman, Heidelberg: Carl-Auer-Systeme, 2000.

Gabriel. G. (1986): "Ein Mann von Welten. Besprechung von Nelson Goodmans ,Weisen der Welterzeugung", in: Philosophische Rundschau 33 (1986), 48-55.

Gabriel, G. (1991): Zwischen Logik und Literatur. Erkenntnisformen von Dichtung, Philosophie und Wissenschaft, Stuttgart: Metzler, 1991.

Gabriel, G. (1997): Logik und Rhetorik der Erkenntnis, Paderborn: Ferdinand Schöningh, 1997.

Gabriel, G. (2000): "Kontinentales Erbe und Analytische Methode. Nelson Goodman und die Tradition", in: Erkenntnis 52 (2000), 185-198.

Genette. G. (1992): Fiction et Diction, Paris: Seuil, 1992.

Genette, G. (1994): L'Euvre de l'Art, Paris: Seuil, 1994. 
Gochet, P. (1972): Esquisse d'une Théorie Nominaliste de la Proposition, Paris: Armand Colin, 1972.

Gombrich, E.H.J. (1960): Art and Illusion. A Study in the Psychology of Pictorial Representation, Princeton: Princeton University Press, 1960.

Gombrich, E.H.J. (1982): The Image and the Eye. Further Studies in the Psychology of Pictorial Representation, Oxford: Phaidon, 1982.

Goodman, N. (1940): A Study of Qualities [1940], Ph.D. Thesis, New York: Garland, 1990.

Goodman, N. (1952): "Sense and Certainty", in: Philosophical Review 61 (1952), 160-167. Reprinted in (PP, 60-68).

Goodman, N. (1969): "Memorial Note", in: K. Lambert (ed.): The Logical Way of Doing Things, New Haven; London: Yale University Press, 1969, ix-x.

Goodman, N. (1983): "Semiotische Ästhetik und pragmatischer Irrealismus", in: Zeitschrift für Semiotik 5 (1983), 256-257.

Goodman, N. (1997): "Some Reflections on my Philosophies", in: Philosophia Scientiae 2 (1) (1997), 15-20.

Goodman, N. (2005): "Gewissheit ist etwas ganz und gar Absurdes" (Nelson Goodman im Gespräch mit Karlheinz Lüdeking), in: Steinbrenner, J.; Scholz, O.R.; Ernst, G. (eds): Symbole, Systeme, Welten. Studien zur Philosophie Nelson Goodmans, Heidelberg: Synchron, 2005, 261-269.

Gosselin, M. (1990): Nominalism and Contemporary Nominalism: Ontological and Epistemological Implications of the Work of W.V. Quine and N. Goodman, Dordrecht: Kluwer, 1990.

Grunstra, B.R. (1972): "Empirical and Conventional Elements in Certain Numerical Laws", in: Rudner, R. and Scheffler, I. (eds): Logic and Art: Essays in Honor of Nelson Goodman, Indianapolis: Bobb-Merrill, 1972, 21-42.

Hacker, P. (1996): Wittgenstein's Place in Twentieth-Century Analytic Philosophy, Oxford: Blackwell, 1996.

Hacking, I. (1965): Logic of Statistical Inference, Cambridge: Cambridge University Press, 1965.

Hahn, L.E. (ed.) (1992): The Philosophy of A.J. Ayer (= The Library of Living Philosophers, Volume XXI), La Salle, Ill.: Open Court Press, 1992. 
Hahn, S. (2000): Überlegungsgleichgewicht(e), Freiburg; München: Alber, 2000.

Hanen, M. (1970): An Examination of Adequacy Conditions for Confirmation, Doctoral dissertation, Brandeis University, 1970.

Hellman, G. (1977): "Introduction", in: $S A$, XIX-XLVII.

Heydrich, W. (1982): Gegenstand und Sachverhalt: Bausteine zu einer nominalistisch orientierten Semantik für Texte, Hamburg: Buske, 1982.

Heydrich, W. (1993): “A Reconception of Meaning”, in: Synthese 95, No. 1 (1993), 77-94.

Hocking, W.E. (1961): "Whitehead as I Knew Him", in: The Journal of Philosophy 58 (1961), 505-516.

Hottinger, S. (1988): Nelson Goodmans Nominalismus und Methodologie, Bern; Stuttgart: Haupt, 1988.

Ihwe, J.F. (1985): Konversationen über Literatur: Literatur und Wissenschaft aus nominalistischer Sicht, Braunschweig: Vieweg, 1985.

Küng, G. (1963): Ontologie und logistische Analyse der Sprache, Wien: Springer, 1963.

Küng, G. (1967): Ontology and the Logistic Analysis of Language, Revised Edition, translated by E.C.M. Mays, Dordrecht: D. Reidel, 1967.

Küng, G. (1977): "Nominalistische Logik heute", in: Allgemeine Zeitschrift für Philosophie 2 (1977), 29-52.

Küng, G. (1993): "Ontology and the Construction of Systems", in: Synthese 95 (1993), 29-53.

Kuklick, B. (1977): The Rise of American Philosophy: Cambridge, Massachusetts 1860-1930, New Haven; London: Yale University Press, 1977.

Kuklick, B. (2001): A History of Philosophy in America 1720-2000, Oxford: Oxford University Press, 2001.

Kulenkampff, J. (1978): "Nelson Goodman, Languages of Art/dt.: Sprachen der Kunst”, in: Philosophische Rundschau 25 (1978), 161-176. Kulenkampff, J. (1981): "Music Considered as a Way of Worldmaking", in: Journal of Aesthetics and art Criticism 39 (1981), 254-258.

Kulenkampff, J. (1997): "Von Einhörnern und Kentauren. Schwierigkeiten mit Goodmans Theorie der Darstellung”, in: J. Nida-Rümelin (ed.): Rationalität, Realismus, Revision, Berlin; New York: de Gruyter, 1997, 761-768. 
Kulenkampff, J. (2005a): "Sind Bilder Zeichen?", in: Steinbrenner, J.; Scholz, O.R.; Ernst, G. (eds): Symbole, Systeme, Welten. Studien zur Philosophie Nelson Goodmans, Heidelberg: Synchron, 2005, 185-201. Kulenkampff, J. (2005b): "Kunst und Erkenntnis. Überlegungen im Anschluß an Nelson Goodman", in: Jäger, C.; Meggle, G. (eds): Kunst und Erkenntnis , Paderborn: Mentis, 2005, 43-61.

von Kutschera, F. (1972): Wissenschaftstheorie, 2 Volumes, München: Fink, 1972.

von Kutschera, F. (1975): "Nelson Goodman: Das neue Rätsel der Induktion”, in: J. Speck (ed.): Grundprobleme der großen Philosophen: Philosophie der Gegenwart III, Göttingen: Vandenhoeck \& Ruprecht, 1975, 51-86.

von Kutschera, F. (2005): "Kunst und Erkenntnis", in: Ch. Jäger and G. Meggle (Hrsg.): Kunst und Erkenntnis, Paderborn: Mentis, 2005, 73-92. Lammenranta, M. (1991): "Do We Make Worlds with Symbols?", in: Semiotica 86 (1991), 277-287.

Lammenranta, M. (1992): “Goodman's Semiotic Theory of Art", in: Canadian Journal of Philosophy 22 (1992), 339-352.

Leonard, H.S. (1930): Singular Terms, Doctoral Dissertation, Widener Library, Harvard University, 1930.

Leonard, H.S., Goodman, N. (1940): "The Calculus of Individuals and Its Uses", in: Journal of Symbolic Logic 5 (1940), 44-55.

Leondar, B.; Perkins, D. (eds) (1977): The Arts and Cognition, Baltimore: Johns Hopkins University Press, 1977.

Lewis, C.I. (1946): An Analysis of Knowledge and Valuation, La Salle, Il: Open Court, 1946.

Lewis, C.I. (1952): "The Given Element in Empirical Knowledge", in: Philosophical Review 61 (1952), 168-175.

Lowe, V. (1990): Alfred North Whitehead: The Man and His Work, Vol. II: 1910-1947, Baltimore; London: Johns Hopkins University Press, 1990.

Mahrenholz, S. (1998): Musik und Erkenntnis. Eine Studie im Ausgang von Nelson Goodmans Symboltheorie, Stuttgart; Weimar: Metzler, 1998, ${ }^{2} 2000$.

McCormick, P.J. (ed.) (1996): Starmaking. Realism, Anti-Realism, and Irrealism, Cambridge, Mass.; London: MIT Press, 1996. 
McDonell, N. (1979): Sight and Symbol, Doctoral Dissertation, Harvard University, 1979.

Mitchell, W.J.T. (1986): Iconology: Image, Text, Ideology, Chicago: University of Chicago Press, 1986.

Mitchell, W.J.T. (1994): Picture Theory. Essays on Verbal and Visual Representation, Chicago; London: University of Chicago Press, 1994.

Mitchell, W.J.T. (1999): "Vim and Rigor", in: Art Forum, May 1999 (URL: http://www.artforum.com/goodman.html).

Morizot, J (1996): La Philosophie de l'Art de Nelson Goodman, Nimes : Editions Jacqueline Chambon, 1996.

Pouivet, R. (1996): Esthétique et logique, Liège: Mardaga, 1996.

Putnam, H (1981): Reason, Truth and History, Cambridge: Cambridge University Press, 1981.

Putnam, H. (1990): Realism with a Human Face, Cambridge, Mass.; London: Harvard University Press, 1990.

Putnam 1992: H. Putnam: Renewing Philosophy, Cambridge, Mass.; London: Harvard University Press, 1992.

Quine, W.V.O. (1985): The Time of my Life, Cambridge, Mass.; London: MIT Press, 1985.

Ridder, L. (2002): Mereologie, Frankfurt am Main: Klostermann, 2002.

Rudner, R. (1967): "Nelson Goodman", in: P. Edwards (ed.), The Encyclopedia of Philosophy, Vol. 3, London; New York: MacMillan, 1967, 370-374.

Rudner, R.; Scheffler, I. (eds) (1972): Logic and Art: Essays in Honor of Nelson Goodman, Indianapolis: Bobbs-Merrill, 1972.

Sachs-Hombach, K.; Rehkämper, K. (eds) (1999): Bildgrammatik. Interdisziplinäre Forschungen zur Syntax bildlicher Darstellungsformen, Magdeburg: Scriptum, 1999.

Scheffler, I. (1963): The Anatomy of Inquiry, New York: Knopf, 1963.

Scheffler, I. (1979): Beyond the Letter: A Philosophical Inquiry into Ambiguity, Vagueness and Metaphor in Language, London: Routledge \& Kegan Paul, 1979.

Scheffler, I. (1986): Inquiries: Philosophical Studies of Language, Science and Learning, Indianapolis: Hacket, 1986.

Scheffler, I. (1991): In Praise of the Cognitive Emotions and Other Essays in the Philosophy of Education, New York; London: Routledge, 1991. 
Scheffler, I. (1997): Symbolic Worlds: Art, Science, Language, Ritual, Cambridge: Cambridge University Press, 1997.

Scheffler, I. (2001): "Nelson Goodman (1906-1998)", in: Martinich, A.P.; Sosa, D. (eds): A Companion to Analytic Philosophy, Oxford: Blackwell, 2001, 160-168.

Schilpp, P.A. (ed.) (1968): The Philosophy of C. I. Lewis (= The Library of Living Philosophers, Volume XIII), La Salle, Ill.: Open Court Press, 1968.

Scholz, H. (1951): "Nelson Goodman, The Structure of Appearance", in: Deutsche Literaturzeitung 72 (1951), 433-434.

Scholz, H. (1958): "Nelson Goodman, Fact, Fiction and Forecast", in: Deutsche Literaturzeitung 79 (1958), 297-298.

Scholz, O.R. (1984): "Fiktionale Welten, mögliche Welten und Wege der Referenz", in: Finke, P.; Schmidt, S.J. (eds): Analytische Literaturwissenschaft, Braunschweig: Vieweg, 1984, 70-89.

Scholz, O.R. (1988): "Catherine Z. Elgin: With Reference to Reference (Book Review)", in: Zeitschrift für philosophische Forschung 42 (1988), 336-340.

Scholz, O.R. (1993a): "Introduction: Reconceptions in Context", in: Synthese 95 (1993), 1-7.

Scholz, O.R. (1993b): “When is a Picture?", in: Synthese 95 (1993), 95106.

Scholz, O.R. (1995): "Künste, Symbolsysteme und die Verbesserung des Verstehens", in: Kunstforum International 131 (1995), 348-351.

Scholz, O.R. (2000): “A Solid Sense of Syntax”, in: Erkenntnis 52 (2000), 199-212.

Scholz, O.R. (2001): “Kunst, Erkenntnis und Verstehen”, in: Kleimann, B.; Schmücker, R. (eds): Wozu Kunst? Die Frage nach ihrer Funktion, Darmstadt: Wiss. Buchgesellschaft, 2001, 34-48.

Scholz, O.R. (2004): Bild, Darstellung, Zeichen. Philosophische Theorien bildlicher Darstellung, Second, revised edition, Frankfurt am Main: Klostermann, 2004.

Scholz, O.R. (2005): "In memoriam Nelson Goodman", in: Steinbrenner, J.; Scholz, O.R.; Ernst, G. (eds): Symbole, Systeme, Welten. Studien zur Philosophie Nelson Goodmans, Heidelberg: Synchron, 2005, 9-32. 
Schwartz, R. (1986): “I'm Going to Make You a Star", in: Midwest Studies in Philosophy 11 (1986), 427-439.

Schwartz, R. (1994): Vision: Variations on Some Berkeleian Themes, Oxford: Blackwell, 1994.

Schwartz, R. (1997): "Goodman, Nelson", in: Garrett, D.; Barbanell, E. (eds): Encyclopedia of Empiricism, Westport, Conn.: Greenwood Press, 1997, 126-128.

Schwartz, R. (1999): “In memoriam Nelson Goodman (August 7, 1906 November 25, 1998)", in: Erkenntnis 50 (1999), 7-10.

Sheffer, H. (1913): "A set of five independent postulates for Boolean algebras, with application to logical constants", in: Transactions of the American Mathematical Society 14 (1913), 481-488.

Sheffer, H. (1921): The general theory of notational relativity, Manuscript, copies in: Sheffer Papers, Cambridge (Mass.): Harvard University, Houghton library.

Stalker, D. (ed.) (1994): Grue! The New Riddle of Induction, Chicago: Open Court, 1994.

Stegmüller, W. (1957): "Nelson Goodman: The Structure of Appearance \& Willard Van Orman Quine: From a Logical Point of View", in: Philosophische Rundschau 5 (1957), 280-292.

Stegmüller, W. (1958/59): “Conditio Irrealis, Dispositionen, Naturgesetze und Induktion ( $\mathrm{Zu} \mathrm{N}$. Goodman: Fact, Fiction, Forecast)", in: KantStudien 50 (1958/59), 363-390.

Stegmüller, W. (1969): Probleme und Resultate der Wissenschaftstheorie und Analytische Philosophie, Band I: Wissenschaftliche Erklärung und Begründung, Berlin; Heidelberg; New York: Springer, 1969.

Stegmüller, W. (1983): Probleme und Resultate der Wissenschaftstheorie und Analytische Philosophie, Band I: Erklärung, Begründung, Kausalität, Second, enlarged edition, Berlin; Heidelberg; New York: Springer, 1983.

Steinbrenner, J. (1996): Kognitivismus in der Ästhetik, Würzburg: Königshausen \& Neumann, 1996.

Steinbrenner, J.; Winko, U. (eds) (1997): Bilder in der Philosophie \& in anderen Wissenschaften und Künsten, Paderborn: Schöningh, 1997. 
Steinbrenner, J.; Scholz, O.R.; Ernst, G. (eds) (2005): Symbole, Systeme, Welten. Studien zur Philosophie Nelson Goodmans, Heidelberg: Synchron, 2005.

Thürnau, D. (1994): Gedichtete Versionen der Welt. Nelson Goodmans Semantik fiktionaler Literatur, Paderborn: Schöningh, 1994.

Volpi, F. (ed.) (1999): Großes Werkelexikon der Philosophie, Vol. I., Stuttgart: Kröner, 1999.

Vuillemin, J. (1971): La Logique et le Monde Sensible, Paris: Flammarion, 1971.

Wang, H. (1986): Beyond Analytic Philosophy. Doing Justice to What We Know, Cambridge, Mass.; London: MIT Press, 1986.

White, M. (1950): "The Analytic and the Synthetic: An Untenable Dualism", in: Hook, S. (ed.): John Dewey: Philosopher of Science and Freedom, New York: The Dial Press, 1950, 316-330.

White, M. (1999): A Philosopher's Story, University Park, PA: Pennsylvania State University Press, 1999.

Whitehead, A.N. (1919): An Enquiry concerning the Principles of Natural Knowledge, Cambridge: Cambridge University Press, 1919. 